\title{
SOUL DEATH AND THE LEGACY OF TOTAL WAR
}

\author{
DAVID T. LOHREY* \\ Charles Stuart University
}

\begin{abstract}
Following the lead of Hannah Arendt and others, I want to argue that the imperial mystique seen in the British Empire found its way into Germany's expansionist ambitions. I am concerned with the emotional costs of oppression, or what I call soul death. I focus on three key writers of the $20^{\text {th }}$ century: Doris Lessing, Nadine Gordimer, and J. M. Coetzee, placing their writings in the context of war trauma and the barbarities associated with $20^{\text {th }}$ century totalitarianism. My argument seeks to elucidate the relationship between postcoloniality and the wars that shaped that century. These narratives of distress will be juxtaposed with novels by Imre Kertész and Arnošt Lustig whose writings of the Holocaust and the war atmosphere on the Eastern Front illuminate scenes of trauma and personal anguish. Here my study draws on the work of recent psychologists whose term soul murder is made much of. These writers' works can be more fully understood to reveal patterns of personal destruction that are part of living under imperialism. They bring to the forefront behaviours that expose the debasement and hardening witnessed in the early decades of the century.
\end{abstract}

KEY WORDS: Holocaust, imperialism, trauma, war, soul

With the world's cultures being ravaged and destroyed, from end to end, by viciously inappropriate technologies, with wars raging everywhere, with whole populations being wiped out, and deliberately, for the benefit of rul-

ing castes, with the wealth of every nation being used almost entirely for war, for preparations for war, propaganda for war, research for war; with the general levels of decency and honesty visibly vanishing, with corruption everywhere-with all this, living in a nightmare of dissolution, was it really possible, it may be asked, for these poor creatures to believe that 'on the whole' all was well? (Doris Lessing 1992: 85-86)

\section{Preliminaries to Soul and Death}

Displacement and estrangement are central themes in the literary works analysed in this paper; my focus will be on personal estrangement in the context of social upheaval and political oppression at mid-20th century. It

* David T. Lohrey (PhD 2012, Charles Stuart University, Wagga Wagga, Australia) is Assistant Professor in English at Tokyo City University in Tokyo, Japan. His interests include political theory, Holocaust studies, and contemporary novelists, such as André Brink, J. M. Coetzee, and Philip Roth. Email: lohr_burg@hotmail.com. 
can, in fact, be argued that writers who explore 'the costs of Britain's ideology of racial supremacy' do so through the prism of mid-20th century experiences, which include both the disintegration of Europe's failed empires and the rise of the century's 'most malignant imperial power, the Third Reich' (Bluemel 2005: 1). Recent events have left some people wondering if this statement can be left unchallenged (Chomsky 2008; Pinter 2005). The focus remains on three key writers of the 20th century: Doris Lessing, Nadine Gordimer, and J. M. Coetzee, but their work will be analysed in the context of war trauma and the barbarities associated with 20th century totalitarianism. This paper's focus will further elucidate the relationship between postcoloniality and the wars that shaped that century.

Imre Kertész, Nadine Gordimer and Arnošt Lustig were all born in the 1920s. Doris Lessing was born in Iran (then Persia) in 1919, but later immigrated with her English parents to South Rhodesia. J. M. Coetzee, was born in 1940 to a family of Dutch settlers in South Africa. Gordimer's parents were both European. Her Lithuanian father had been a Jewish refugee in czarist Russia. Lessing was a communist at one time; she and Lustig both left their native lands

to live in political exile. Lessing left Rhodesia for London; Lustig left his native Czechoslovakia for the United States in 1968. George Steiner was born in 1929 in Vienna, the same year as Kertész. His family fled Hitler's armies, making their way first to Paris and then to New York. Edward Said became an American citizen, although born to a Christian family in Jerusalem. Homi Bhabha, who is from Mumbai, teaches in the United States, as do Chinua Achebe and Chenjerai Hove. The tensions they narrate between estrangement and human connection may be traced to similarities they share as refugees, émigrés, and exiles. The Europeans come either from Austria, Hungary or Czechoslovakia, including those areas at the borderlands of the Habsburg Empire, such as Lithuania, the area Gordimer's father fled to come to South Africa. George Steiner has characterised his generation of Europeans in such a way as to redefine what it means to be an artist in such a time: 'It seems proper', he writes, 'that those who create art in a civilization of quasi-barbarism which has made so many homeless, which has torn up tongues and peoples by the root, should themselves be poets unhoused and wanderers across language' (Steiner: 1971: 11).

These narratives all depict humans in various states of incapacity, held against their will, bewildered by the unknown and rendered unrecognizable to themselves. Moments of intimacy are both treasured and lost. The possibility of human contact is foreclosed. That authors of such diverse backgrounds should situate their protagonists in such familiar states of distress invites comparison. What they have in common is what Said has said characterises the 20th century, namely, 'modern warfare, imperialism, and the quasi-theological ambitions of totalitarian rulers' (Said 1993: 174). That 
world, although acknowledged as fractured, is to be renewed, according to Homi K. Bhabha, in his effort to reassemble a world of shared meanings:

What must be mapped as a new international space of discontinuous historical realities is, in fact, the problem of signifying the interstitial passages and processes of cultural difference that are inscribed in the 'in-between', in the temporal break-up that weaves the 'global' text. It is, ironically, the disintegrative moment, even movement, of enunciation-that sudden disjunction of the present-that makes possible the rendering of culture's global reach (Bhabha 1994: 310).

It is also to be considered that aspects of this discontinuity offer opportunities for reformulation. When considered in light of the trauma and repercussions of war, some of what looks to be inexplicable may be traced to the catastrophes of the 20th century.

One way these authors express the coincidence of their backgrounds is through their anatomising of themes of reeducation and adjustment to new worlds. Fourteen-year-old George Koves, the young protagonist in Imre Kertész's Fateless, experiences the labour and death camps where he was held as opportunities for learning. 'What was important', young George learned and now seeks to pass on, 'was that you should not let yourself go: somehow things would work out, because it never happened that they didn't work out. So Bandi Citrom taught me as he, in turn, had been taught this wisdom earlier in his labor camp' (Kertész 1992: 100). It is doubtful that it does in fact always turn out this way, but like a traditional coming-ofage novel, Fateless functions much the same as July's People and Lovely Green Eyes do, namely, as primers for living, offering advice, as it were, on making-do, facing the facts, and surviving in a new world, while enveloped by brooding anticipation and memories of death.

Less optimistically, one might understand the adolescent protagonist's experience as an example of what therapist Dr. Leonard Shengold has termed soul murder as, he says, 'a term I have used for the apparently willful abuse and neglect of children by adults that are of sufficient intensity and frequency to be traumatic. By that I mean that the children's subsequent emotional development has been profoundly and predominantly negatively affected; what has happened to them has dominated their motivating unconscious fantasies; and they have become subject to the compulsion to repeat the cruelty, violence, neglect, hatred, seduction, and rape of their injurious past' (Shengold 1991).

It is obviously no exaggeration to say that the traumatising experiences of 20th century prisoners of war, victims of the Holocaust, and other atrocities including apartheid resembled the atmosphere or circumstances of those described by Dr. Shengold. In Kertész's 2002 Nobel Prize acceptance 
speech, the author of Fateless reviewed his experiences in the camps and his writing process:

I might have tried to break up time in my novel, and narrate only the most powerful scenes. But the hero of my novel does not live his own time in the concentration camps, for neither his time nor his language, nor even his own person, is really his. He doesn't remember; he exists. So he has to languish, poor boy, in the dreary trap of linearity and cannot shake off the painful details. Instead of a spectacular series of great and tragic moments, he has to live through everything, which is oppressive and offers little variety, like life itself (Kertész 2002).

Kertész, a concentration camp survivor, connects Fateless to the novel's attempts to address the truth of his own experiences. That experience demands, according to the author, its own artistic form, for the sake of the reality of the experience. What the author was trying to capture was the unbelievability of the experience. He feared through abstraction that merely the 'idea' of the camps would survive, so he chose to concentrate on the details, even those that were unimportant:

Now I understood how and why in those humiliating twenty minutes of idleness and helplessness, clarity faded from their memories. And when I thought how all this repeated the same way for days, weeks, months and years on end, I gained an insight into the mechanism of horror; I learned how it became possible to turn human nature against one's own life (Kertész 2002).

Perhaps the author means that the experience in Auschwitz cannot be made to rise to any conceptual clarity, perhaps that its extraordinary specificity must be given its place in everyday experience, perhaps that we must simply make room for it as a reality. Kertész wants the extermination camps to be remembered, but not as an idea, not as a conceptual event that happened back then, but as actual experience, an extraordinary actual experience that not only happened, but happens. Kertész's efforts spring from his awareness of a phenomenon identified by Dori Laub as belonging to traumatic events, namely, in a 'collapse of witnessing' (Laub 1995: 68). This can be described as a crucial aspect belonging to events like the Holocaust; they resist comprehension. 'The force of this experience would appear to arise precisely in other words, in the collapse of understanding' (Caruth 1995: 9). Kertész's literary strategy arises from this insight. 'In my writings, the Holocaust could never be present in the past tense' (Kertész 2002).

The themes of dislocation and trauma that are found in the writings of Gordimer, Lessing, and Coetzee can also be seen in writers such as Kertész and Lustig who, according to Sven Lindqvist, have lived in political environments of striking similarity: 
Lindqvist shows how there was a remarkable congruence between the language employed by the colonial apologists and the language Conrad appropriated for the insane ramblings of Kurtz. Lindqvist maintains that the colonial racism of the Victorians was a precursor to the Nazi quest for Lebensraum and the extermination of the Jews... (Marrouchi 2008: 4).

The trauma of survival and annihilation is one link between these authors. Ethnic cleansing on the Eastern Front lies at the heart of Arnošt Lustig's fiction. In Lovely Green Eyes (2000), the protagonist witnesses first-hand the extermination camps and survives by sexually pleasuring the men responsible. After the war, Rabbi Schapiro tries to make sense of what had happened to this most vulnerable witness, but he has trouble taking it all in:

He had heard, though not at first hand, how the master race had populated the lands between the Elbe and the Urals by clearing them of their original inhabitants. How the armies of the Herrenvolk had opened the spaces in the east in order to turn them into a home for 200 million Germans by exterminating tens of millions, from infants to the elderly (Lustig 2000: 158).

Genocide and mass killings are not easily made the subject of fiction. In the context of such overwhelming barbarity, intimate moments may be shown to illuminate the wider destruction.

One key is to be found in the following description of a hospital ward at Auschwitz in which Kertész's protagonist finds himself. George's bewilderment and his own recognition of the utter arbitrariness of his situation is a persistent theme:

Still, I came to think, this place is no stranger, really, than all the other strange possibilities, one way or another, good or bad, in a concentration camp. On the other hand, this place disturbed me, made me uneasy, and undermined my sense of security. After all, if I examined it logically, I could find no acceptable reason for finding myself here instead of somewhere else (Kertész 1992: 151).

He can no more make sense of his present surroundings than the doctors who work in the hospital. The following exchanges between the boy, who is only 14, and the adults who work in the ward would make for hilarious comedy in the hands of a clever satirist. Here, in Kertész's fiction, the material is more disturbing than funny. And, again, while one is tempted to cover such events in easy clichés about bureaucracy and a lack of caring, the harm done to those who survived can much more dramatically if not accurately be described by the term soul murder, which is to say, permanently scarred, or marked for life.

It is as though the doctors and nurses were psychologically crippled, incapacitated by an emotional reaction they had long forgotten. Kertész's pro- 
tagonist sees in the adults at the clinic a striving for sympathy, but it somehow remains at a distance:

I felt that somehow they felt good about, even received some pleasure from, this feeling of sympathy. Maybe I was mistaken, but I didn't think I was. At other times when they asked me questions, interrogated me, I had the impression that they were actually exploring the opportunity to find a way, an excuse, for feeling this emotion, looking for some reason, some need of a proof of something, perhaps of the fact-who knows? - that they were still capable of feeling sympathy (Kertész 1992: 155).

One wonders if they are capable of feeling anything, least of all sympathy or compassion for others. 'In the age of the concentration camp, castration is more characteristic of social reality than competitiveness' (Jay 1973: 105). This statement made by Sigmund Freud summarises the mental as well as the physical conditions described by Kertész, and points to the signal characteristic of the totalitarian state, which is, according to Hannah Arendt, to 'liquidate all spontaneity' (Heather and Stolz 1979: 14), which is another way of saying that their souls were to be extinquished. One might even say, it was an effort to rob people of their souls, an effort to make one a stranger to other human beings.

\section{Rhetoric of Empire}

The experiential link between victims of the Holocaust and those traumatised by colonialism and apartheid can be found in the ways language was used to erase human feeling. Achebe's harrowingly accurate rendering of administrative rhetoric expresses the distance colonial authorities placed between themselves and the native populations (New 1996). In Things Fall Apart that distance is made explicit. Colonial discourse overwhelms Achebe's recreation of an indigenous voice (Innes 1996: 134). According to James Snead, "political appropriation and co-optation as historical fact here are mirrored in the insistence of white discourse; the attempt of the 'white' narrative to usurp or 'universalise' the 'black' one, with all its quaint heritage of “"Native customs and idiom"” (Snead 1990: 243).

The District Commissioner in Things Fall Apart is no more able to express compassion than the doctors at Auschwitz are able to express sympathy for a young boy who does not understand why he has been taken from his family. The Commissioner's resolve to write a book to be entitled The Pacification of the Primitive Tribes of the Lower Niger captures the sensibility of inhumane indifference. Even the rhetoric of Empire was killing. The Kafkaesque cruelty finds many forms in the 20th century; here it is shown with devastating perception as an arrogant nonchalance in the face of human tragedy: 
Every day brought him some new material. The story of this man who had killed a messenger and hanged himself would make interesting reading. One could almost write a whole chapter on him. Perhaps not a whole chapter but a reasonable paragraph, at any rate. There was so much else to include, and one must be firm in cutting out details (Achebe 1994: 209).

Achebe succeeds at so many levels in getting right the inhumanity of the exchange. A new 'English' suddenly intrudes itself on the scene, spoken by an agent of imperial power, his language of indifference cutting as deep as the blade of a guillotine. The scene resonates because it is at once of the moment and frighteningly expressive of an entire age.

As Snead points out, what is taken over and eradicated is the capacity to express the human. George Steiner, on the subject of the degradation of the German language in the 20th century, speaks directly to this process of deracination, arguing that a rhetoric of indifference replaced the once humanistic language of the German poets, which had extolled the presence of the human soul:

Thus university, officialdom, army, and court combined to drill into the German language habits no less dangerous than those they drilled into the German people: a terrible weakness for slogans and pompous clichés (Lebensraum, 'the yellow peril', 'the Nordic virtues'); an automatic reverence before the long word or the loud voice; a fatal taste for saccharine pathos (Gemütlichkeit) beneath which to conceal any amount of rawness or deception (Steiner 1971: 97).

The jarring contrast between Achebe's native idiom and that of the colonial administrators is found by Steiner in pre- and postwar Germany. It is one feature of our current 'global culture' that has emerged, if not of the one envisioned by Homi Bhabha, that bureaucratic rhetoric debases communication.

According to Truusje Roegholt, one of the Holocaust survivors interviewed by journalist Geert Mak, 'People simply didn't talk. The Third Reich was a dictatorship based, to a great extent, on silence' (Hastings 2008: 245). According to Max Hastings's review of the recently translated volume of Germany and the Second World War, German wartime society is described as having engaged in a systematic conspiracy of silence; most of the society, in fact, colluded in Nazi crimes through their enforced silence, having participated in or benefited from the regime's policies:

The 'collective silence' that took root in the two German societies did not cover just the crimes of the Nazi state; it took in as well the perpetrators of them, those who profited from them, and their minor accomplices. Perhaps this was because everyone had, before 1945, themselves benefited from the Nazi regime in one way or another (Hastings 2009: 18). 
Dutch novelist Paul Verhaeghen (2007) reflects back on the connection between silence and atrocity, concluding, as do Geert Mak and Max Hastings, that silence gave cover to the Nazis; it was a vital part of the terror because it enabled the perpetrators:

In other words, violence reigned, and it was freely expressed in all its explosive force. The SA had a town full of accomplices. Screams can only blossom in silence. Friedrichstraße, Rosinestraße-these streets lie in the very heart of the city. The nighthawks who roamed from jazz club to beer cellar must have heard the cries of pain. They chose to remain deaf (Verhaeghen 2007: 129).

The issue of estrangement or 'extraterritoriality', as it called by George Steiner (1971), is both central to writers of war trauma, political oppression and genocide. Central, because each author creates a setting and a narrative that invites the protagonist(s) to learn and adapt, as an adventurer does, and because writers such as Gordimer and Lustig consider the implications of their protagonists imprisoned among strangers. In this connection, they belong to the idiom of Kafka. Kafka's work embodies what Deleuze and Guattari have called 'minor literature', because, among other things, it is characterised by 'the deterritorialization of language' (Deleuze and Guattari 1986: 18). This description can be applied to writing that captures experiences of estrangement: curiosity, a sense of wonder if not of bewilderment but, most importantly, the sense either that one can no longer communicate or that one cannot make oneself understood in an alien and alienating environment.

Because the world itself can no longer be comprehended, the authors' project is described by Deleuze and Guattari as a 'literature of lament and of mental restlessness' (1986: 46). This project of discovery and exposure, however, does not extend to human sexuality. That this is true for these authors suggests a link between the political and cultural impoverishment of the lives depicted and the end, temporary or permanent, of sexual intimacy.

The innocent have a lot to learn. Lustig wants to take things back to their origins, not just to first principles, but to one's instincts for survival. Everything has to be learned anew, but in matters of life and death a reliance on animal cunning may get one through. Hanka Kaudersová, a 15 year-old Jewish girl known as Skinny, is eager to be accepted as a Feldure, or army prostitute:

Skinny had already lost everyone she could lose; but she had not yet lost herself and did not wish to. It was a primitive instinct, but it was the only thing she could hold on to. She refused to let it distort her outward appearance: the Hauptsturmfuehrer mustn't suspect what she was feeling. Pity was not a Nazi 
characteristic. She was going through a selection, of a kind they had at Auschwitz-Birkenau every Monday, morning and evening (Lustig 2000: 15).

She knows that she must pass for 18 and as a gentile in order to work in Feldbordell No. 232 Ost, serving officers. As is the case for Maureen and Bam Smales, Gordimer's protagonists in July's People, the obstacle to understanding things as they are is often one's reliance on the past. One is unable to see what lies right before one's eyes because one wants to hold on to what is familiar and comfortable. Skinny, soon to be accepted as a field prostitute on the Eastern Front, knows that if she falters or is detected, she'll be sent to the gas chambers, where her family has been killed:

There was no way back now. She gave her old Prague address to avoid making a mistake later on. She heard herself speaking as if the voice were not her own. Her blood was no longer throbbing in her temples as it had while she was waiting her turn. She tried not to think of their Prague flat which had been taken over by the Zentralstelle fuer juedische Auswanderung. The Germans had made sure that the flat would go to a German (Lustig 2000: 16).

Gertjejanssen's research confirms that hardships of this kind were common to the lives of female Jews, Baltics, and Slavs who were taken into what she calls 'a horrifying workload' (2004: 2). To survive, Skinny learns to lie, and lives, but does so as does Kertész's young protagonist, by growing numb to his surroundings, by being less than human, by closing his eyes. By the logic of the screening officer, Skinny's previous work in the hospital caring for the sick and dying qualified her to service the sexual needs of officers at the front (Lustig 2000: 16). She would soon know the reason:

The troops come here shaken by the battering they've received, confused by defeats for which nothing has prepared them. They no longer look like the flower of Germany, as they had after defeating Poland and France. They no longer believe that nothing could stop them until they reached the foot of the Urals. Now they were a master race with sore bottoms, inflamed foreskins and swollen feet, with water on the knees, with prominent varicose veins. Their eyes are bloodshot with fatigue. They come to the brothel as if to a field hospital (Lustig 2000: 192).

Despite the weakened condition of the Nazis, Skinny and her fellow prostitutes were in no position to resist their demands and were brutally whipped when their services fell short of expectation. Catherine A. MacKinnon reminds readers that prostitution has more to do with domination than with pleasure: 'As it is in this war, prostitution is forced on women everyday: what is a brothel but a captive setting for organised serial rape?' (MacKinnon 2007: 161). 
The Smales, on the other hand, have lived a lie, and must now face painful truths. Thus incarcerated, the protagonists undergo an education in living in a real world, which may or may not resemble the world of their experiences or of their imaginations. As the Smales make their adjustments to living in the bush, as they are re-educated in the ways, if not of the world, then of life in a small village, they grow less and less able to think of each other sexually. It is as though in direct proportion to their loss of worldly possessions, they become physically less attractive to each other: 'The baring of breasts was not an intimacy but a castration of his sexuality and hers; she stood like a man stripped in a factory shower or a woman in the ablution block of an institution' (Gordimer 1981: 90). Curiously, the imagery is reminiscent of the institutions described by Kertész and Lustig. She is depicted as a prisoner, institutionalized, dehumanized, and soulless. She has become a thing in Bam's eyes, perhaps like Kafka's Gregor Samsa. She is repellent: 'The tight T-shirt dragged down her features, distorting eyes, nose and mouth. It was as if she grimaced at him, ugly; and yes she was his "poor thing", disheveled by living like this, obliged to turn her hand to all sorts of unpleasant things' (Gordimer 1981: 90). Bam sees Maureen as a repulsive creature, made so by the contingency of a changed environment. Bam's notion of intimacy is dependent on circumstance. Evidently, he can live with this. It is less clear that Maureen can. Maureen's self-recognition undermines her capacity for intimacy. Impotence accompanies powerlessness. Before the revolution, as it were, Maureen had operated on a concept of universality which made it possible for her to set moral absolutes by which to live and love. 'The humane creed (Maureen, like everyone else, regarded her own as definitive) depended on validities staked on a belief in the absolute nature of intimate relationships between beings' (Gordimer 1981: 64). She comes to see that her absolutes are dependent on circumstance, perhaps on race, but certainly on chance: 'We' (Maureen sometimes harked back) 'understand the sacred power and rights of sexual love as formulated in master bedrooms, and motels with false names in the register. Here, the sacred power and rights of sexual love are as formulated in a wife's hut, and a backyard room in a city' (Gordimer 1981: 65).

Maureen comes to the realisation that her universals are merely circumstantial; everything has depended on their having belonged to a colonising nation with a racist national policy. This discovery for her is a matter of shame if not of disgust. Maureen can no longer love her husband, nor can she make love to him, for reasons as simple as the fact that they are both filthy, the hut is full of fleas, but more importantly because July, by taking away their car and gun, or in permitting these things to be stolen, has undermined their authority, and to their minds, their humanity. In the 
Smales, one can almost hear Gregor Samsa's plaintive cry to be allowed to live as he had always lived:

Did [Gregor] really want his warm room, so comfortably fitted with old family furniture, to be turned into a naked den in which he would certainly be able to crawl unhampered in all directions but at the price of shedding simultaneously all recollections of his human background (Kafka 1971: 116).

To 'understand the sacred power and rights of sexual love as formulated in master Bedrooms' requires that there be a bedroom but, much more importantly, that there be a master. Although Gordimer may be the kind of writer 'for whom White mythologies in the mould of Out of Africa are abhorrent', she is unwilling to consider the possibility of making July Maureen's new master (Simoes da Silva 2002: 4).

Gordimer moves away from the stereotype that is so commonplace in the literature of empire, that of the servants who remain silent and have no right to voice their own opinions. Gordimer does not reverse this order, but in Maureen the author has created a character with the intelligence to recognise, if not accept, her own loss of authority. Although supposedly trusted by Maureen, July was never treated as an equal. Now living away from home in the village of July's people, the Smales must watch as July takes over. Maureen, July tells her, used to check her things back in town just as she and Bam 'check' their things while in July's village. It is the loss of the gun and their car keys that make them see the writing on the wall. It is July and not Bam who actually holds power in the village where the Smales are staying:

And here; what was he here, an architect lying on a bed in a mud hut, a man without a vehicle. It was not that she thought of him with disgust-what right had she, occupying the same mud hut—but that she had gone a on a long trip and let him behind in the master bedroom: what was here, with her, was some botched imagining of his presence of his presence in circumstances outside those the marriage was contracted for (Gordimer 1981: 98).

If Maureen has become less of a woman in Bam's eyes, he has become less of a man in hers. They have become less attractive to each other, are in fact no longer attracted to each other in large part because they no longer recognise each other's worth. As words left them, so did physical intimacy, because both had been inexorably linked.

This kind of repartee belonged to the deviousness natural to suburban life. In the master bedroom, sometimes it ended in brief coldness and irritation, sometimes in teasing, kisses and love-making of a variety suggested by the opportunities of the room and its rituals-a hand between her legs while she was cleaning 
her teeth, the butting of his penis, seeking her from behind while she bent over the bath to swish a mixture of hot and cold water (Gordimer 1981: 89).

Without the domestic rituals, the coordinates of love escaped their attention. Their intimacy depended on bath water: 'They had not made love since the vehicle had taken them away. Unthinkable, living and sleeping with the three children there in the hut. A place with a piece of sacking for a door. Lack of privacy killed desire; if there had been any to feel-but the preoccupation with daily survival, so strange to them, probably had crowded that out anyway' (Gordimer 1981: 79).

Between Maureen and Bam Smales, there had, in fact, been no intimate relations since leaving their home and their possessions. Their dispossession had left Bam impotent; without their home they no longer have sexual desire for each other. Nor did they have sexual feelings for others. They had both been effectively neutered by their dispossession, a critical part of their identities erased. In contrast, what inflames the passion of Mary Turner, Doris Lessing's protagonist in The Grass Is Singing, cannot be reduced easily to a single cause. One of them is certainly her servant's raw physicality. Unlike Bam Smales' observation of his wife's body, which he found a gross turnoff, Mary is intoxicated by the presence of Moses: 'She used to sit quite still, watching him work. The powerful, broad-built body fascinated her. [His clothes] were too small for him; as he swept or scrubbed or bent to the stove, his muscles bulged and filled the thin material of the sleeves until it seemed they would split' (Gordimer 1981: 161).

Mary's fascination can be understood as an exchange by which the observer, in this case, Mary Turner, is altered by what she sees. While fascinated, Mary was also repelled, both by the man and by her reaction: 'Vividly she pictured the broad muscular back, and shuddered. So clear was her vision of the native that she imagined she smelled the hot acrid scent of native bodies. She could smell it, lying here in the dark' (Lessing 1984: 184). Mary's racism makes her quite literally hysterical, as she is unable to cope with her sexual attraction to a black man: 'It was like a nightmare where one is powerless against horror: the touch of this black man's hand on her shoulder filled her with nausea; she had never, not once in her whole life, touched the flesh of a native' (Lessing 1984: 172).

Mary Turner's confinement is not an elaboration of a visionary theme, but 'social and actual' (Lessing 1984: 86). Mary's alienation is not only internal, but physical in the sense that she is living in isolation on a piece of land that is literally nearly featureless. At the same time, her mental torment moves from the real to the fantastic. She imagines that she will be ensnared by the black man who has become as object of revulsion in her mind, a giant insect, waiting to devour her: 'Now it seemed as if the night were closing in on her, and the little house was bending over like a candle, melting in the 
heat. She heard the crack, crack; the restless moving of the iron above, and it seemed to her that a vast black body, like a human spider, was crawling over the roof, trying to get inside' (Lessing 1984: 234). This provocative, frightening imagery reinforces one's sense that her imagination offers no hope for escape. She simply cannot imagine her way out of her desperation, and yet her nightmare comes to an end, albeit brutal.

Mary Turner and Maureen Smales are both overtaken by the force of nature, freed in a sense from the annihilating power of domesticity. They escape their respective traps. Mary is murdered. 'The trees advanced in a rush, like beasts, and the thunder was the noise of their coming' (Lessing 1984: 236). Maureen takes off. Both acts are assertions of desperation. Gilbert and Gubar identify these 'moments of escape' as projections of the female author:

For it is, after all, through the violence of the double that the female author enacts her own raging desire to escape male houses and male texts, while at the same time it is through the double's violence that this anxious author articulates for herself the costly destructiveness of anger repressed until it can no longer be contained (Lessing 1984: 85).

Mary and Maureen lose whatever powers they once had or imagined themselves to have had. They found themselves living in triangles of increasing powerlessness at the hands of men, black and white. They both lost confidence in their husbands but could not cope with the possibility of relations with a black man. Mary's breakdown is closely observed by a young Englishman. Tony has occasion to evaluate Mary's relationship with Moses, which has grown intimate, but assumes it is limited to her allowing Moses to undress her. He comments that Mary's behaviour reminds him of European aristocracy. He says, 'There was once an Empress of Russia who thought so little of her slaves, as human beings, that she used to undress naked in from of them.' Mary Turner, although no aristocrat, fancies herself the superior of the natives. Her sexual fantasies clash with her racist fancies. 'A white person may look at a native, who is no better than a dog' (Lessing 1948: 163). What she finds unforgivable in Moses is his assumption that he is a human being.

Nudity cuts both ways. Mary's loss of shame is related to her dehumanisation of Moses, but it is also related to her estrangement. Her mental breakdown grows out of her isolation, social and sexual. Tony sees Moses' undressing of Mary as a profound transgression, immediately recognising Mary's intimacy with Moses as a breakdown of barriers with wide-ranging implications. Tony's mind wanders between Moses' threatening gaze and Mary's apparent indifference. In The Wretched of the Earth, Fanon argues 
colonial relations were ruled by an awareness on the part of settlers like Lessing's Turners and Gordimer's Smales of their vulnerability:

The zone where the natives live is not complementary to the zone inhabited by the settlers. The two zones are opposed, but not in the service of a higher unity. Obedient to the rule of Aristotelian logic, they both follow the principle of reciprocal exclusivity. No conciliation is possible, for of the two terms, one is superfluous. The town belonging to the colonised people, or at least the native town... is a place of ill fame, peopled by men of evil repute... The colonised man is an envious man. And this the settler knows very well; when their glances meet he ascertains bitterly, always on the defensive. 'They want to take our place' (Fanon 1990: 39).

Doris Lessing's Mary Turner pursues her servant with the eyes of a paranoid, precisely, as Fanon insists, because of his threatening self-confidence. Lessing exposes through what Tony witnesses in Mary's bedroom the vulnerability of the colonial edifice. By his having seen Moses helping Mary into her clothes, Tony intuits that far more is at stake than the loss of her husband's honour. The personal becomes political, as it does for Chenjerai Hove (1990). The image of the exposed female alerts the male to alterations and usurpations of power. The man recognises that it is he who is unmanned by the presence of the naked woman: 'Manyepo, look at my bare breasts, and these cracked feet, do you not think that my feet should be covered so that I can work better in the muddy soil of your fields? All the children staring at a woman's bare breasts, do you not think it is shameful? Why do you not give your own wife that chance to go around half-naked with flies cleaning their coats on her nipples?' (Hove 1990: 17).

The issue of nakedness is made relevant by inequality and exploitation. It is not that she is naked, but that the overseer's inhumanity makes her feel vulnerable and mortified by his indifference.

Such experiences as described by Hove and Lustig may make one wonder about Young George's observation in Kertész's Fateless, to the effect that 'somehow things would work out, because it never happened that they didn't work out' (Kertész 1992: 100). Here we find events described with such lacerating pain that it not only discredits George's momentary optimism as a kind of lapse, but it brings into question Bhabha's tendency to locate in the postcolonial project signs of hope. At other times, however, he advocates relationships 'where non-consensual terms of affiliation may be established on the grounds of historical trauma', which seems more persuasive, as does his borrowed expression, 'freak social and cultural displacements' (Kertész 1992: 17).

There may, however, have been more at stake in the postcolonial analysis of settler discomfort, even with its menacing implications. The silences 
and distances have also to do with reminders of racial prejudice and miscegenation. Fear is something that dominates and finally overwhelms. This is the experience July has over the Smales; it is new to them and utterly unsettling. The silences and awkwardness are products of man's doings; they are part of the discourse of colonialism, part of the rhetoric of death. Benedict Anderson ties colonial racism's disturbing conceit to European antiSemitism:

The fact of the matter is that nationalism thinks in terms of historical destinies, while racism dreams of eternal contaminations, transmitted from the origins of time through an endless sequence of loathsome copulations: outside history Niggers are, thanks to the invisible tar-brush, forever niggers; Jews, the seed of Abraham, forever Jews, no matter what passports they carry or what languages they speak and read (Anderson 2006: 149).

Racism's 'eternal' characteristics may be what Anderson claims them to be; what concerns us here is racism in the historically specific moment of colonialism.

One can speak of an entire generation having shared a world haunted by war. People lived haunted by the spectre of war, its propaganda, and then its consequences. Richard J. Evans, in his recent The Coming of the Third Reich suggests that the atmosphere for Hitler's rise was established early in the century: 'The First World War legitimised violence to a degree that not even Bismarck's wars of unification in 1864-70 had been able to do' (Evens 2003: 72). The War brought out the worst in people, creating an atmosphere of incivility and incipient violence that ran from the streets into parliament. Evans continues: 'Those who carried out these acts of violence were not only former soldiers, but also included men in their late teens and twenties who had been too young to fight in the war themselves and for whom civil violence became a way of legitimizing themselves in the face of the powerful myth of the older generation of front-soldiers' (Evens 2003: 72-73).

This coarsening of civic life will be seen later in an America crippled by decades of wars. Non-combatants, men and women, came to share the life of veterans, either in anticipation of impending conflicts or in memory of those already endured. Men and women became veterans, even if it only meant having to live among those ravaged and unable to adjust to so-called peace.

\section{Surviving an Inhuman Hegemony}

Shared political realities make comparison possible between peoples of disparate ancestries and origins. An effort has been made to show how displacement and estrangement characterise victims of colonialism. Physical 
withdrawal and isolation were both a consequence and a cause of such estrangement. Mary Turner's isolation and gradual madness are both cause and effect of what Homi Bhabha has termed 'unhomely moments', which occur 'in fictions that negotiate the powers of cultural difference in a range of transhistorical sites' (Bhabha 1994: 13). For Mary, isolation began sexually, as she forfeited passion as a survival strategy: 'It was not so bad, she thought, when it was all over: not as bad as that. It meant nothing to her, nothing at all. Expecting outrage and imposition, she was relieved to find she felt nothing. She was able maternally to bestow the gift of herself on this humble stranger, and remain untouched' (Lessing 1948: 56).

Of course, Mary is not able to 'remain untouched'. She has in fact negotiated an isolation that violates her equilibrium. Mary's transgressions were engendered by her humiliation.

In their discussion of Hannah Arendt's Origins of Totalitarianism, Heather and Stolz describe Arendt's concept of 'world alienation' in such a way as can be applied to Bhabha's search for a global culture living in the shadow and under threat of war:

The events, [Arendt] argues, that favored the triumph of total domination (war, revolution, vast economic dislocation) all combined to shatter the normal structures of social and political order. They produced, as a consequence, a society flooded by atomised masses who felt themselves powerless before events Arendt labels 'world alienation'. All this, she writes, 'sprang from a chaos of mass perplexities on the political scene and of mass opinions in the spiritual sphere which the totalitarian movements, through ideology and terror, crystallised into new forms of government and domination (Heather and Stolz 1979: 16).

Despite living in a world of 'mass perplexities', these writers have not succumbed to Steiner's 'temptation of silence', but rather have worked to give voice to their experiences of the era's special brand of hell. Silence has, however, not been rejected as a strategy of survival, as will be shown in Coetzee's own Disgrace. Lustig, like Coetzee and Gordimer, invents a kind of hell on earth to expose the cost of remaining silent for too long.

These works of fiction share settings of social discord in times of real or imagined crisis. Lustig and Gordimer create environments of confinement in the larger context of upheaval and revolution. These authors use individual struggles against hopelessness and powerlessness. Fateless and Lovely Green Eyes are set in or near Nazi concentration camps. Lessing's protagonist remains confined by the circumstances of rural isolation and by social conventions of colonialism. In J. M. Coetzee's Disgrace (1999), these themes are developed further to include a consideration of the moral dimension of resignation. The gap that opens up between the married couples in The Grass Is Singing and in July's People parallels the gulf between David Lurie 
and his daughter Lucy. An awakening occurs in the women, however subtle, which results in an awareness that their own identity is inexorably tied to racial subjugation, an awareness which is confirmed by MacKinnon's research on the subject of rape as an instrument of genocide (2006).

David Lurie and his daughter Lucy experience a sense of increasing isolation and fear. Intruders finally break in. First, they kill Lucy's dogs, and then attack and burn David, while others take Lucy to a back room to have their way with her. Paralysed as much by confusion as by fear, David's reaction is that of the intellectual who suddenly recognises the limits of a lifetime's cultivation of the mind:

He speaks Italian, he speaks French, but Italian and French will not save him here in darkest Africa. He is helpless, an Aunt Sally, a figure from a cartoon, a missionary in cassock and topi waiting with clasped hands and upcast eyes while the savages jaw away in their own lingo preparatory to plunging him into their boiling cauldron (Coetzee 1999: 95).

Coetzee explores in Disgrace what in Slow Man he has called elsewhere 'the underside' (Coetzee 2006: 125). In Disgrace, and according to David Lodge, elsewhere, Coetzee depicts sex as 'phallic, compulsive, obsessive, and rather joyless...' One might add: helpless, forced. This is quite suddenly Gordimer's world. Lustig's Professor David Lurie and his daughter Lucy have been reduced to objects. In July's People, the Smales fall apart when they lose control of their car, when they could no longer control their lives. As in Bones, Disgrace and Lovely Green Eyes, women are reduced to sexual objects for barter. They are rude commodities savaged by force or by consent, in episodes of commerce. The disgrace is not that of individual immorality but of a disordering of meaning. They are victims of a kind of code of annihilation that barters dignity. As Catherine A. MacKinnon has written, 'Women are abused by men in these ways every day in every country in the world. Sex has also been used before to create, mobilise, and manipulate ethnic hatred, from the world of the Third Reich to the world of Penthouse' (MacKinnon 2007: 161).

Coetzee, Gordimer, and Lessing seem determined to display the ambivalent effects of colonisation. Lucy, Maureen, and Mary are forced to see themselves and respond to their respective shocks of recognition in different ways. Maureen and Lucy eventually come to see themselves, in Albert Memmi's words, as usurpers (1967: 9). Lucy sees all too well what has happened to her as a political act. There has been a seizing of control in the act of violating her. Lucy stops her father from calling the police when he sees that the men who raped her are known in the neighborhood: 'Don't shout at me, David. This is my life. I am the one who has to live here. What happened to me is my business, mine alone, not yours, and if there is one right 
I have it is the right not to be put on trial like this, not to have to justify myself-not to you, not to anyone else' (Coetzee 1999: 133). Unlike her father, who believes he is acting out of personal concern and love, Lucy recognises that her violation represents a transfer of power, one that she chooses not to resist:

As for Petrus, he is not some hired labourer whom I can sack because in my opinion he is mixed up with the wrong people. That's all gone, gone with the wind. If you want to antagonise Petrus, you have better be sure of your facts. You can't call the police. I won't have it (Coetzee 1999: 133).

The stakes, Lucy recognises, are high. According to Catherine A. MacKinnon: 'Violating other men's women is planting a flag; it is a way some men say to other men, 'What was yours is now mine'. He who gets away with this, runs things. Doing this institutionalises the rulership of some men over other men even as it establishes the rulership of all men over all women' (2007: 171). Lucy understands this and accepts it. She sees her acceptance as a political act of a kind, an act of reconciliation. Her father, the intellectual, does not and cannot. It is as though sex is a thing to be possessed and owned, or that through possession or dispossession, one gains or loses sexual power. MacKinnon's analysis goes right to the heart of the exchange between Lucy and the men who raped her; she has been taken over by them, along with her house and her land. Now that they have the land, Petrus promises, they will leave her body alone (Coetzee 1999: 138). MacKinnon and Leonard Shengold see sexual brutality as permanent injuries and while soul murder is Shengold's term, Mackinnon speaks of trauma in a way that echoes his emphasis on permanent injury.

This inquiry has ventured into areas of contemporary literature that reflect the phenomenon of the displaced author. Each author, although unique, expresses a collective preoccupation with cross-cultural and transnational experience of loss. In what Homi Bhabha described as 'mimicry', they are confronted and challenged by losses of autonomy and threatened by forces that are deeply subversive and which bear traces of mockery and menace. Consequently, the authority of colonial discourse as represented by these authors is threatened and the colonial domination is weakened if not overcome. Still, the authors share in a desire to force a recognition if not an action. They are hopeful that the discourse of regeneration can be forged without denial. Holocaust survivor Imre Kertész concludes his Nobel Lecture by asking that the Holocaust not be cast as an historical event, but as something we can come to terms with in the present:

The problem of Auschwitz is not whether to draw a line under it, as it were; whether to preserve its memory or slip it into the appropriate pigeonhole of his- 
tory; whether to erect a monument to the murdered millions, and if so, what kind. The real problem with Auschwitz is that it happened, and this cannot be altered-not with the best, or worst, will in the world... since Auschwitz we are more alone, that much is certain (Kertész 2002).

From this the importance of the Holocaust is clear. It is present, and its presence not only defines us but, if Kertész is right, limits us. Hannah Arendt sees a loss of freedom in our isolation. She writes: 'What prepares men for totalitarian domination in the non-totalitarian world is the fact that loneliness, once a borderline experience usually suffered in certain marginal social conditions like old age, has become an everyday experience of the ever-growing masses of our century' (Arendt 1964: 475). The isolated, politically atomised man can still work, or labour, can still fall back on the intimacies and support of private life, as men have done under many tyrannies. But totalitarianism is not content with creating isolation. It invades the private sphere as well. It is based on loneliness dominating both the political and social spheres of life. As a result, Kertész locates the Holocaust in the present as a condition of our times and as a warning:

Remembrance of the Holocaust is important to stop such things from happening again. But, in fact, nothing has happened since Auschwitz that would prevent another Auschwitz from happening. On the contrary. Before Auschwitz, the extermination camp was unimaginable. Today, it can be imagined. Because Auschwitz really happened, it has permeated our imagination, become a permanent part of us. What we are able to imagine-because it really happenedcan happen again (Kertész 2006).

Professor Gabriel Motzkin extends Kertész's point when he makes the following statement: 'This means that we are a new event after the Holocaust. In other words, it means that I am a post-Holocaust, a post-war person, a postwar post-Holocaust person, and so is everybody else' (Motzkin 1998). What Motzkin articulates from one perspective can be recognised as an affirmation of the concerns of Homi Bhabha and the attempt by postcolonial writers to establish connections between colonialism and globalism. That connection must be made through the 20th century, two world wars, and the Holocaust. As Bhabha writes: 'This global link between colony and metropolis, so central to the ideology of imperialism, is articulated in Kurtz's emblematic words—“the Horror, the Horror!"' (Bhabha 1994: 304).

\section{Conclusions}

In this paper, I have attempted to show how memories of war play out psychologically, revealed in intimate moments, where vulnerability and powerlessness are shown to be the cost of political oppression. The rise of German tyranny in the 20th century is found to be the template for inhumanity, not 
an historical anomaly but a model of brutality. The postcolonial writers of Southern Africa, Lessing, Gordimer, and Coetzee, are seen to produce works that echo the narratives of brutality produced in central Europe in the wake of Hitler's armies. Their works, too, are seen in light of their own histories, their European backgrounds, an inheritance of displacement and dislocation. Critics may seek to draw absolute distinctions between political regimes, suggesting that personal experiences cannot so easily be compared. Here, I have suggested that such comparisons deserve consideration as a way to better understand continuity in politics. I have tried to promote an interpretation of imperialism that recognises the imperial dynamic of oppression. This argument rests on an interpretation of imperial intent offered by Hannah Arendt and others who see totalitarianism as a political means of destroying human spontaneity of action irrespective of its peculiar historical characteristics. In this connection, the Holocaust cannot be dismissed as an historical anecdote, but recognized as offering a prism through which to understand threats of political domination and dehumanisation. Thus anchored, a coherent, multifaceted attitude toward imperial power emerges.

One sees in Gordimer's, Lessing's, and Coetzee's works an alertness to the fragility of human freedom. This awareness echoes and reinforces depictions of human exchange by Holocaust survivors such as Imre Kertész and Arnošt Lustig. Theirs are narratives of frailty and survival. These works show how the machinery of the state breaks people personally, leaving survivors alive but soul dead. The violation of an individual's dignity is experienced profoundly, while the state's propagandists proclaim the diminishment of the individual. These works collectively call for the need for vigilance, aware as they are that what we have is easily undermined and destroyed. The juxtaposition of authors of different lands offers one a fresh perspective. I propose new understandings of the ways individuals experience political domination. These writers offer new insights into the ways rapid social change can undermine human rights. These authors test our ability to believe in the myth of progress. At the same time, their works emphasise the chance for survival through awareness and responsible action. Hopelessness is not their message, but neither is hopefulness. Their works

reverberate with past trauma and there is no sense in their work that the worst has been done and is now behind us.

\section{Bibliography}

Achebe C (1994) Things Fall Apart. New York, NY: Anchor. Anderson B (2006) Imagined Communities. London: Verso. Arendt H (1964) Origins of Totalitarianism. New York, NY: Meridian Books. Arendt H (1961) Between Past and Present. New York, NY: Beacon Press. 
Bhabha HK (1994) The Location of Culture. London: Routledge.

Bluemel K (2005) Review of Colonial Strangers: Women Writing the end of the British Empire, by Phyllis Lassner. Modernism/modernity 12 (1): 186-188.

Caruth C, ed (1995) Trauma: Explorations in Memory. Baltimore, MD: Johns Hopkins University Press.

Chomsky N (2008) The Essential Chomsky [edited by Anthony Arnove]. New York, NY: The New Press.

Coetzee JM (1999) Disgrace. New York, NY: Viking.

Coetzee JM (2003) Elizabeth Costello. London: Secker \& Warburg.

Coetzee JM (2007) Inner Workings, Literary Essays 2000-2005. New York, NY: Viking.

Coetzee JM (2006) Slow Man. London: Vintage Books.

Deleuze G and Guattari F (1986) Kafka: Toward a Minor Literature [translated by Dana Polan]. Minneapolis, MN: University of Minnesota Press.

Elkins C (2005) Imperial Reckoning: The Untold Story of Britain's Gulag in Kenya. New York, NY: Henry Holt.

Evans RJ (2007) Immoral Rearmament, review of The Wages of Destruction: The Making and Breaking of the Nazi Economy by Adam Tooze. The New York Review 76-78.

Evans RJ (2003) The Coming of the Third Reich. New York, NY: Penguin.

Fanon F (1990) Wretched of the Earth. New York, NY: Penguin.

Gertjejanssen WJ (2004) Victims, Heroes, Survivors: Sexual Violence on the Eastern Front During World War II. PhD Thesis, University of Minnesota.

Gilbert SM and Gubar S (1984) The Madwoman in the Attic: The Woman Writer and the Nineteenth-Century Literary Imagination. New Haven, CT: Yale University Press.

Gordimer N (1981) July's People. New York, NY: Viking Penguin.

Hastings M (2009) A Farewell to Arms, review of The White War: Life and Death on the Italian Front, 1915-1919 by Mark Thompson. The New York Review 11(*): 48-51.

Hastings M (2009) Germans Confront the Nazi Past, review of Jörg Echternkamp (ed) Germany and the Second World War, volume IX/I: German Wartime Society, 1939-1945: Politicization, Disintegration, and the Struggle for Survival. The New York Review 26: 16-18.

Hastings M (2008) The Most Evil Emperor, review of Hitler's Empire: How the Nazis Rules Europe by Mark Marzower. The New York Review 46-49(*): n.p.

Heather G and Stolz M (1979) Hannah Arendt and the Problem of Critical Theory. The Journal of Politics 41(*): 26.

Hove C (1990) Bones. London: Heinemann. 
Innes CL (1996) 'Forging the Conscience of Their Race': Nationalist Writers. In King B (ed) New National Post-Colonial Literatures. Oxford: Clarendon Press.

Jay M (1973) The Dialectical Imagination: A History of the Frankfurt School and The Institute of Social Research, 1923-1950. Boston, MA: Little, Brown.

Kafka F (1998) The Castle [translated by Mark Harman]. New York, NY: Schocken Books.

Kafka F (1971) The Complete Stories. New York, NY: Schocken Books.

Kertész I (1992) Fateles [translated by Christopher C. Wilson and Katharina M. Wilson]. Evanston, IL: Northwestern University Press.

Laub D (1995) Truth and Testimony: The Process and the Struggle. In Caruth C (ed) Trauma: Explorations in Memory. Baltimore, MD: Johns Hopkins University Press.

Lessing D (1992) Canopus in Argos: Archives. New York, NY: Vintage.

Lessing D (1948) The Grass Is Singing. New York, NY: Schribner's.

Lodge D (2003) Disturbing the Peace, review of Disgrace by J. M. Coetzee. The New York Review 20 November. Available online for consultation on http//www.nybooks.com/articles/16791: 5.

Lustig A (2000) Lovely Green Eyes [translated by Ewald Osers]. New York, NY: Arcade Publishing.

MacKinnon CA (2007) Are Women Human? And Other International Dialogues. Cambridge: The Belkap Press.

Memmi A (1967) The Coloniser and the Colonised. Boston, MA: Beacon Press.

Pinter H (2006) Nobel Lecture 2005: Art, Truth \& Politics. PMLA 121(3): 811-818.

Said EW (1994) Culture and Imperialism. New York, NY: Vintage.

Said EW (2000) Reflections on Exile. In Said EW (ed) Reflections on Exile. Cambridge, MA: Harvard University Press.

Shengold L (1991) Soul Murder Revisited: Thoughts about Therapy, Hate, Love, and Memory. New York, NY: Ballentine.

Simoes Da Silva T (2002) African childhoods: identity, race and autobiography. Mots Pluriels 22: 4.

Snead J (1990) European pedigrees/African contagions: nationality, narrative, and communality in Tutuola, Achebe, and Reed. In Bhabha HK (ed) Nation and Narration. London: Routledge.

Steiner G (1971) Extraterritorial: Papers on Literature E The Language Revolution. New York, NY: MacMillan.

Steiner G (1998) Language and Silence: Essays on Language, Literature, and the Inhuman. New Haven, CT: Yale University Press.

Verhaeghen P (2007) Omega Minor. Champaign, IL: Dalkey Archive Press. 


\section{Internet sources}

Kertész I (2002) Heureka! [translated by Ivan Sanders].

http://nobelprise.org/nobel_prises/literature/laureates/2002/Kertesz-lecturee.html.

Kertész I (2009) The Freedom of Bedlam. http://www.signandsight.com/features/908.html.

Marrouchi MB (2008) 'Horrors'. www.countercurrents.org, 2011 January. Motzkin G (1998) An Interview. Shoah Resource Center, the International School for Holocaust Studies, 8/14. 7 January and 8 July 2009. Available on www. yadvashem.org. 